\title{
Dopaminergic regulation of avian prolactin gene transcription
}

\author{
A Al Kahtane, Y Chaiseha ${ }^{1}$ and M El Halawani \\ Department of Animal Science, University of Minnesota, St Paul, Minnesota 55108, USA \\ ${ }^{1}$ School of Biology, Institute of Science, Suranaree University of Technology, Thailand \\ (Requests for offprints should be addressed to M El Halawani; Email: elhal001@umn.edu)
}

\begin{abstract}
It is well documented that prolactin (PRL) release and PRL gene expression in birds are controlled by the tonic stimulation of hypothalamic vasoactive intestinal peptide (VIP). However, there is good evidence that dopamine (DA) exerts both stimulatory (at the hypothalamic level) and inhibitory (at the pituitary level) effects on PRL secretion. The interactions between VIP and DA in the regulation of PRL gene transcription are not known. This study was designed to examine the effects of a $D_{2} D A$ receptor agonist $\left(\mathrm{D}_{2} \mathrm{AG} ; \mathrm{R}(-)\right.$-propylnorapomorphine $\mathrm{HCl}$ ) on basal and VIP-stimulated PRL gene transcription rate, $\mathrm{PRL}$ mRNA steady-state levels, PRL mRNA stability and PRL release from cultured turkey anterior pituitary cells. The $D_{2} A G\left(10^{-10} \mathrm{M}\right)$ completely inhibited the stimulatory effect of VIP $\left(10^{-7} \mathrm{M}\right)$ upon nascent PRL mRNA as determined utilizing a nuclear run-on transcription assay. To examine further the effect of the $\mathrm{D}_{2} \mathrm{AG}$ on PRL mRNA post-transcriptional events, anterior pituitary cells were treated with different concentrations of $D_{2} A G\left(10^{-12}-10^{-4} \mathrm{M}\right)$. Semi-quantitative RT-PCR and RIA were performed to determine the levels of PRL mRNA and PRL content in the medium respectively. The results show that $\mathrm{D}_{2} \mathrm{AG}$ inhibited VIP-stimulated PRL mRNA steady-state levels as well as basal and VIP-stimulated PRL release, effects which were diminished by the $D_{2}$ DA receptor antagonist, $S(-)$-eticlopride $\mathrm{HCl}\left(10^{-10} \mathrm{M}\right)$. Actinomycin $D(5 \mu \mathrm{g} / \mathrm{ml})$, an inhibitor of mRNA synthesis, was used to assess the effect of $D_{2} A G$ on PRL mRNA stability in response to VIP. The stimulatory effect of VIP on PRL mRNA stability was completely negated by the $D_{2} A G$ (from a half-life of $53.0 \pm 2.3 \mathrm{~h}$ in VIP-treated cells to $25.5 \pm 1.6 \mathrm{~h}$ in $\mathrm{D}_{2} \mathrm{AG}+\mathrm{VIP}$-treated cells, $\left.P \leq 0.05\right)$. These results support the hypothesis that VIP and DA play a major role in the regulation of PRL gene expression in avian species, at both the transcriptional and post-transcriptional levels. In addition, these findings suggest that the DAergic system inhibits PRL release and synthesis by antagonizing VIP at the pituitary level via $D_{2}$ DA receptors.
\end{abstract}

Journal of Molecular Endocrinology (2003) 31, 185-196

\section{Introduction}

It has been established for some time that prolactin (PRL) secretion in avian species is under tonic stimulatory control exerted by the hypothalamus (Kragt \& Meites 1965, Bern \& Nicoll 1968) and several lines of evidence indicate that vasoactive intestinal peptide (VIP) is the PRL-releasing factor (PRF) in birds (for review see El Halawani et al. 1997). In contrast to birds, the identity of the physiological PRF in mammals remains unascertained (Ben-Jonathan et al. 1989, Freeman et al. 2000, Taylor \& Samson 2001). A group of factors, mostly neuropeptides, have been shown to exhibit stimulatory effects on PRL release. Among them are thyrotropin-releasing hormone (TRH) (Curlewis et al. 2002, Kanasaki et al. 2002, Yuan \& Pan 2002) and the newly described PRL-releasing peptides (Hinuma et al. 1998, Curlewis et al. 2002). However, PRL release from the anterior pituitary is regulated principally by inhibitory influences imparted by the tuberoinfundibular dopamine (DA) system (Ben-Jonathan et al. 1977, Pasqualini et al. 1988, Ben-Jonathan \& Hnasko 2001). In avian species, the role of DA in regulating PRL secretion is still largely obscure. DA, or the DA agonist, 
apomorphine, reduces PRL secretion caused by the co-incubation of chicken and pigeon pituitary glands with hypothalamic extract, an effect which is reversed by the DA receptor antagonist pimozide (Hall \& Chadwick 1983). In the chicken, DA inhibits the release of PRL stimulated by TRH, hypothalamic extract, or by previous exposure of the pituitary gland to estrogen (Hall \& Chadwick 1984). Specific DA-binding sites identified in the anterior pituitary are found to be more abundant in laying than in incubating hens (Macnamee \& Sharp 1989). Moreover, in cultured turkey pituitary cells, $\mathrm{D}_{2}$ DA receptor agonists $\left(\mathrm{D}_{2} \mathrm{AGs}\right)$ inhibit VIP-stimulated PRL release and PRL mRNA steady-state levels (Xu et al. 1996). Data from in vivo studies suggest that DA has both stimulatory and inhibitory effects on turkey PRL secretion (Youngren et al. 1995, 1996b). The presence of both $\mathrm{D}_{1}$ and $\mathrm{D}_{2} \mathrm{DA}$ receptor mRNA in the turkey brain and pituitary (Schnell et al. 1999, Chaiseha et al. 2003) suggests that DA may exhibit biphasic actions within the turkey hypothalamus and pituitary gland. DA appears to regulate PRL secretion centrally through stimulatory $\mathrm{D}_{1}$ and inhibitory $\mathrm{D}_{2}$ DA receptors, while at the pituitary level it exhibits an inhibitory effect on PRL secretion induced by VIP or electrical stimulation (Youngren et al. 1998).

DA plays an intermediary role in PRL secretion, requiring an intact VIPergic system in order to release PRL (Youngren et al. 1996b). Dynorphin, serotonin, DA and VIP all appear to stimulate avian PRL secretion along a pathway expressing К-opioid, serotonergic, DAergic, and VIPergic receptors at synapses arranged serially in that functional order, with the VIPergic system as the final mediator (for review see El Halawani et al. 2000). The anatomical distribution of the avian DAergic system apparently resembles that of mammals (Moons et al. 1994), as DA neurons are found throughout the avian hypothalamus (Kiss \& Peczely 1987, Reiner et al. 1994, Al-Zailaie \& El Halawani 2000).

The tripeptide hypothalamic-releasing factor, TRH, and the avian PRF, VIP, produce a stimulation of PRL transcription (Camper et al. 1985, Yan et al. 1991, Tong et al. 1998), and DA effects a transcriptional repression of the PRL gene in cultured rat anterior cell lines (Elsholtz et al. 1991, Fischberg \& Bancroft 1995). However, the combined effects of these factors on PRL gene
A)
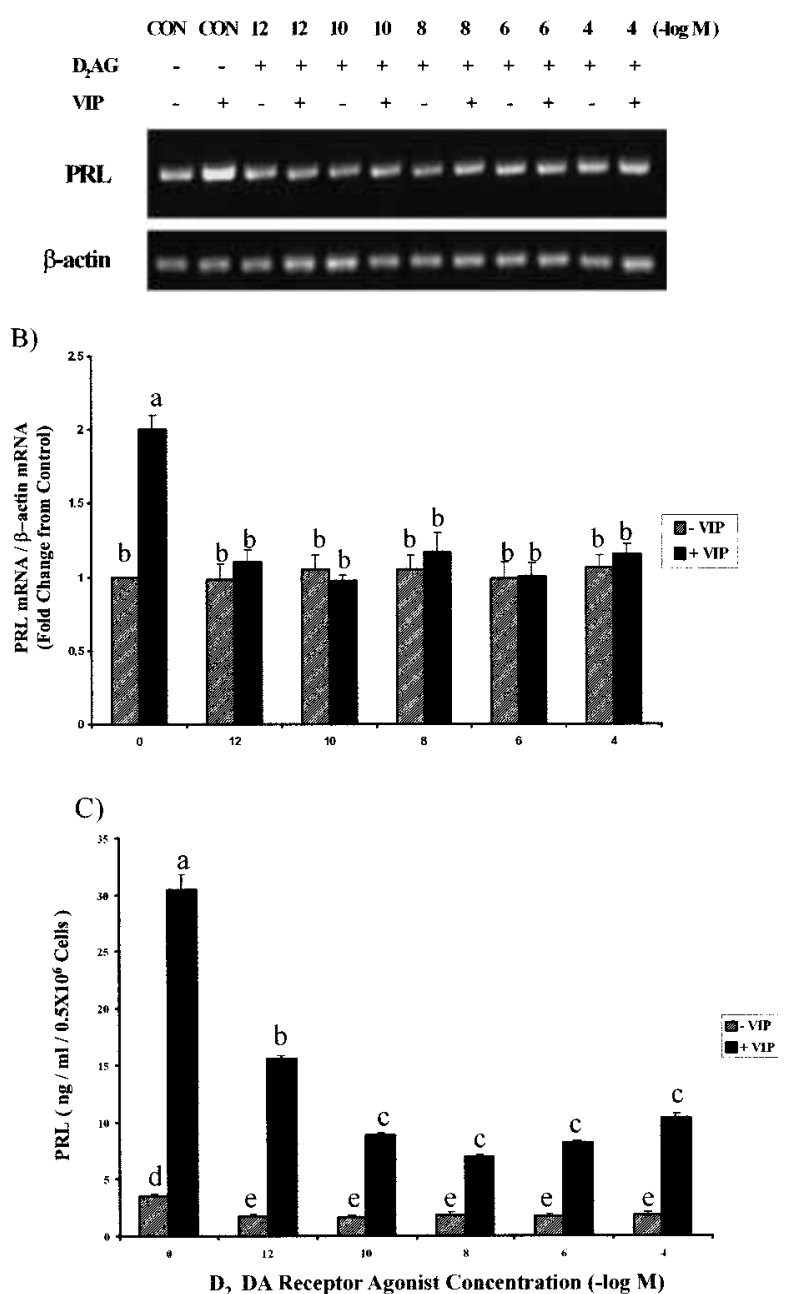

Figure 1 Dose-response effects of a $D_{2} A G$ on basal and VIP-stimulated PRL mRNA expression levels and PRL release in cultured turkey anterior pituitary cells. Cultured pituitary cells $\left(0.5 \times 10^{6}\right.$ cells/treatment) were preincubated with either vehicle (control) or varying concentrations $\left(0,10^{-12}, 10^{-10}, 10^{-8}, 10^{-6}\right.$ and $\left.10^{-4} \mathrm{M}\right)$ of the $\mathrm{D}_{2} A G \mathrm{R}(-)$-propylnorapomorphine for $30 \mathrm{~min}$, followed by subsequent incubation with or without VIP $\left(10^{-7} \mathrm{M}\right)$ for $3 \mathrm{~h}$. (A) Representative photographs of separated RT-PCR products of PRL and $\beta$-actin on ethidium bromide-stained agarose gel. (B) Relative quantification of PRL mRNA levels, which were normalized by endogenous $\beta$-actin mRNA levels. Values (means \pm S.E.M., $n=6$ ) of three different experiments, with two replicates per treatment were expressed as fold changes from vehicle-treated control (basal) values, which were assigned a value of 1.0. (C) Dose-dependent inhibition of basal and VIPstimulated PRL release by the $\mathrm{D}_{2} \mathrm{AG}(n=6)$. Significant differences $(P<0.05)$ are identified by different letters. 
A)

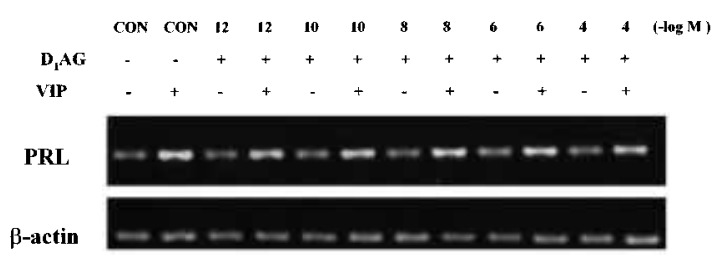

B)

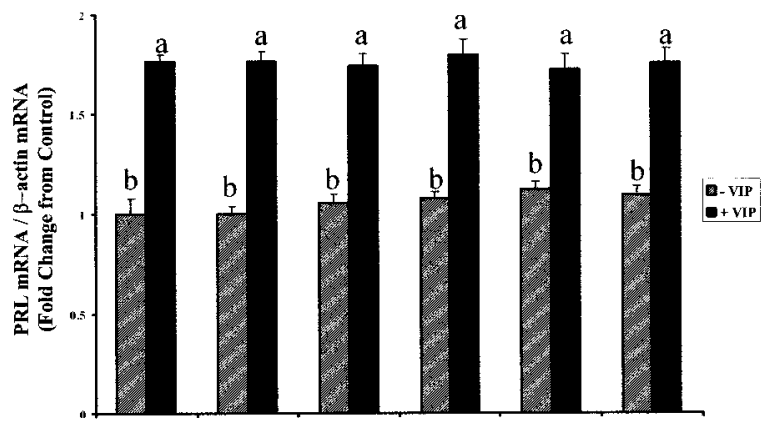

C)

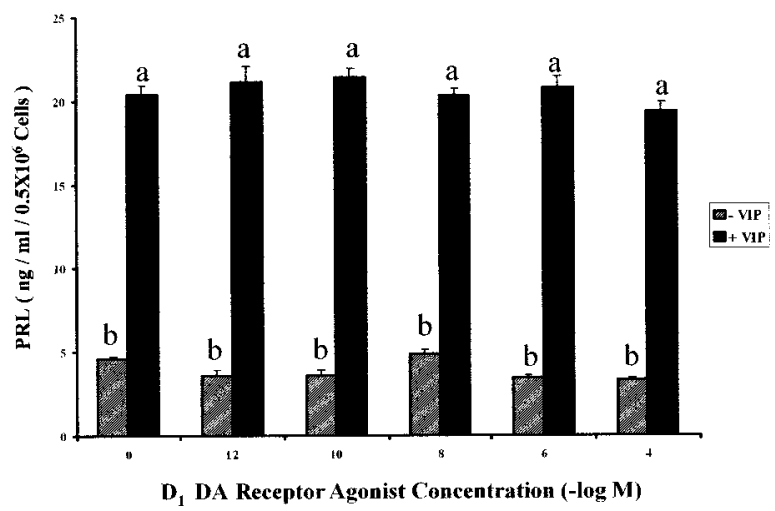

Figure 2 Dose-response effect of a $D_{1} A G$ on basal and VIP-stimulated PRL mRNA expression levels and $P R L$ release in cultured turkey anterior pituitary cells. Cultured pituitary cells were preincubated with either vehicle or varying concentrations $\left(0,10^{-12}, 10^{-10}\right.$, $10^{-8}, 10^{-6}$ and $\left.10^{-4} \mathrm{M}\right)$ of the $\mathrm{D}_{1} \mathrm{AG}(+)$-SKF 38393 for $30 \mathrm{~min}$, followed by subsequent incubation with or without VIP $\left(10^{-7} \mathrm{M}\right)$ for $3 \mathrm{~h}$. See Fig. 1 legend for details.

transcription remain largely unexplored. The aims of the present study were: (i) to investigate the interaction between VIP and DA in regulating PRL gene transcription rate, using the nuclear run-on (NRO) transcription assay, and (ii) to explore further the effects of VIP/DA on PRL mRNA steady-state levels, PRL mRNA stability (half-life), and PRL release from cultured turkey
A)

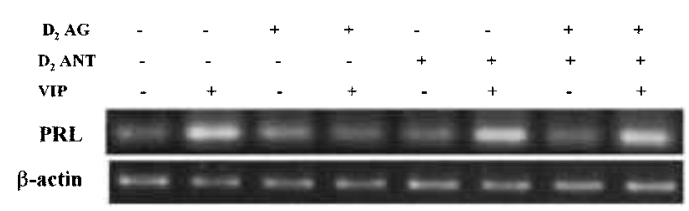

B)

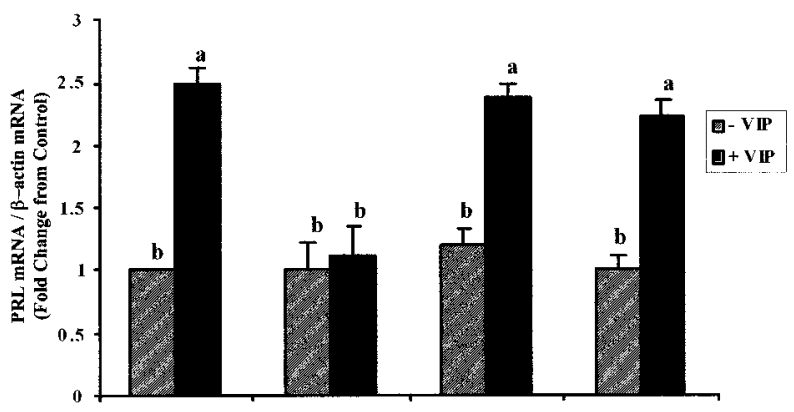

C)

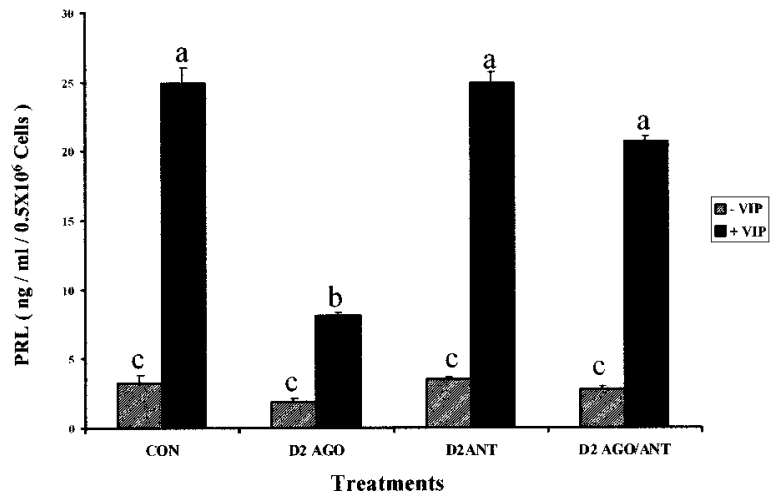

Figure 3 The specificity of the $D_{2} A G$ in inhibiting basal and VIP-stimulated PRL mRNA expression levels and $P R L$ release in cultured turkey anterior pituitary cells. Cultured pituitary cells $\left(0.5 \times 10^{6}\right.$ cells/treatment) were treated as follows: treatment 1 , vehicle for $3 \mathrm{~h}$ and $45 \mathrm{~min}$; treatment 2, vehicle for $45 \mathrm{~min}$ and then cVIP $\left(10^{-7} \mathrm{M}\right)$ was added for $3 \mathrm{~h}$; treatment $3, \mathrm{D}_{2} \mathrm{AG}$ $\mathrm{S}(-)$-eticlopride, $\left(10^{-10} \mathrm{M}\right)$ was added for $3 \mathrm{~h}$ and 45 min; treatment $4, D_{2}$ DA receptor antagonist $\left(10^{-10} \mathrm{M}\right)$ for $45 \mathrm{~min}$ and then cVIP $\left(10^{-7} \mathrm{M}\right)$ was added for $3 \mathrm{~h}$; treatment 5 , vehicle for $15 \mathrm{~min}$, then $D_{2} A G\left(10^{-10} \mathrm{M}\right)$ was added for $3 \mathrm{~h}$; treatment 6 , vehicle for $15 \mathrm{~min}$, then $D_{2} A G$ for $30 \mathrm{~min}$, then $\mathrm{cVIP}$ for $3 \mathrm{~h}$; treatment 7: $\mathrm{D}_{2}$ DA receptor antagonist for $15 \mathrm{~min}$, then $D_{2} A G$ was added for $3.5 \mathrm{~h}$; and treatment $8, D_{2}$ $D A$ receptor antagonist for $15 \mathrm{~min}$ and then $D_{2} A G$ was added for $30 \mathrm{~min}$ and then cVIP for $3 \mathrm{~h}$. See Fig. 1 legend for further details. 
A

$\begin{array}{cccc}1 & 2 & 3 & 4 \\ - & 4 & \end{array}$

$\mathbf{0 ~ h}$

$\begin{array}{cccc}1 & 2 & 3 & 4 \\ 4 & -5 & \end{array}$

$24 \mathrm{~h}$

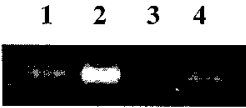

$36 \mathrm{~h}$

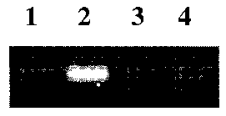

$48 \mathrm{~h}$

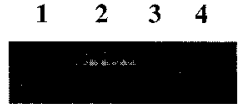

$60 \mathrm{~h}$

$1=$ Control

$2=\operatorname{VIP}\left(10^{-7} \mathrm{M}\right)$

$3=\mathrm{D}_{2} \mathrm{AG}$

$4=D_{2} A G\left(10^{-10} M\right)+V I P$

$B$

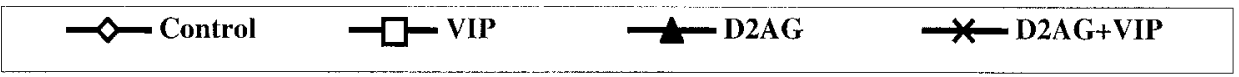

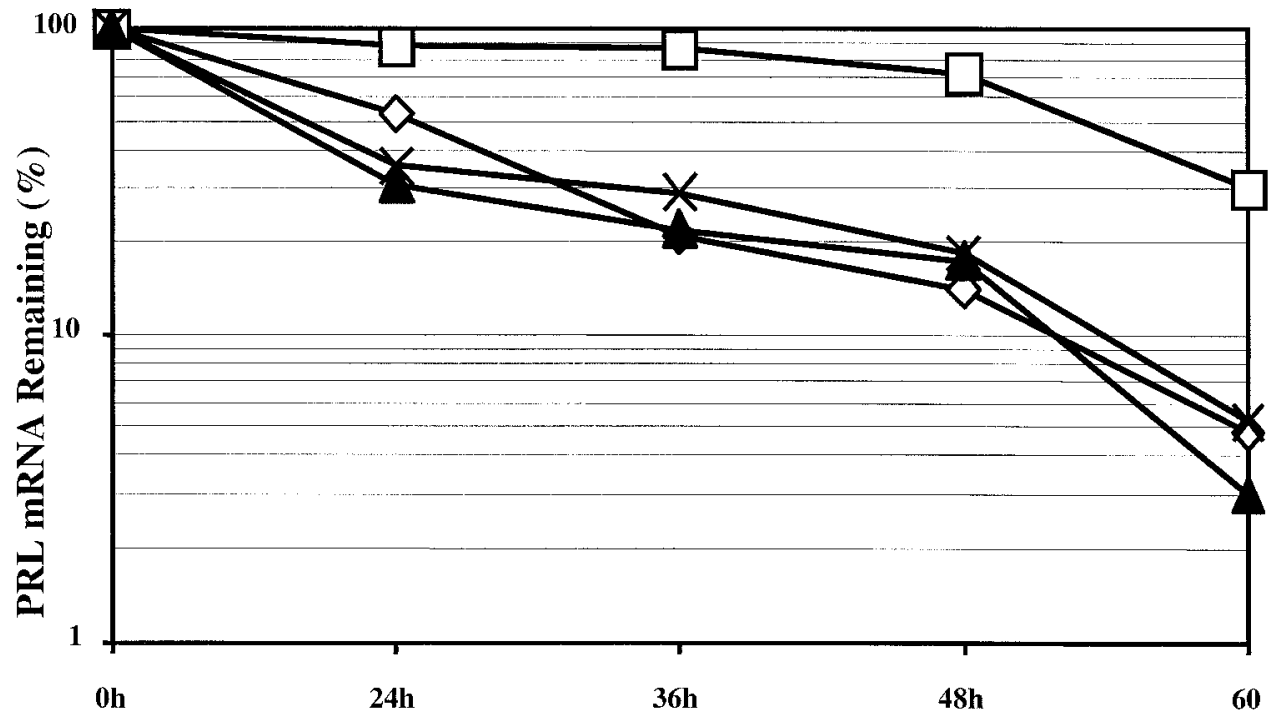

Hours after Addition of Actinomycin D

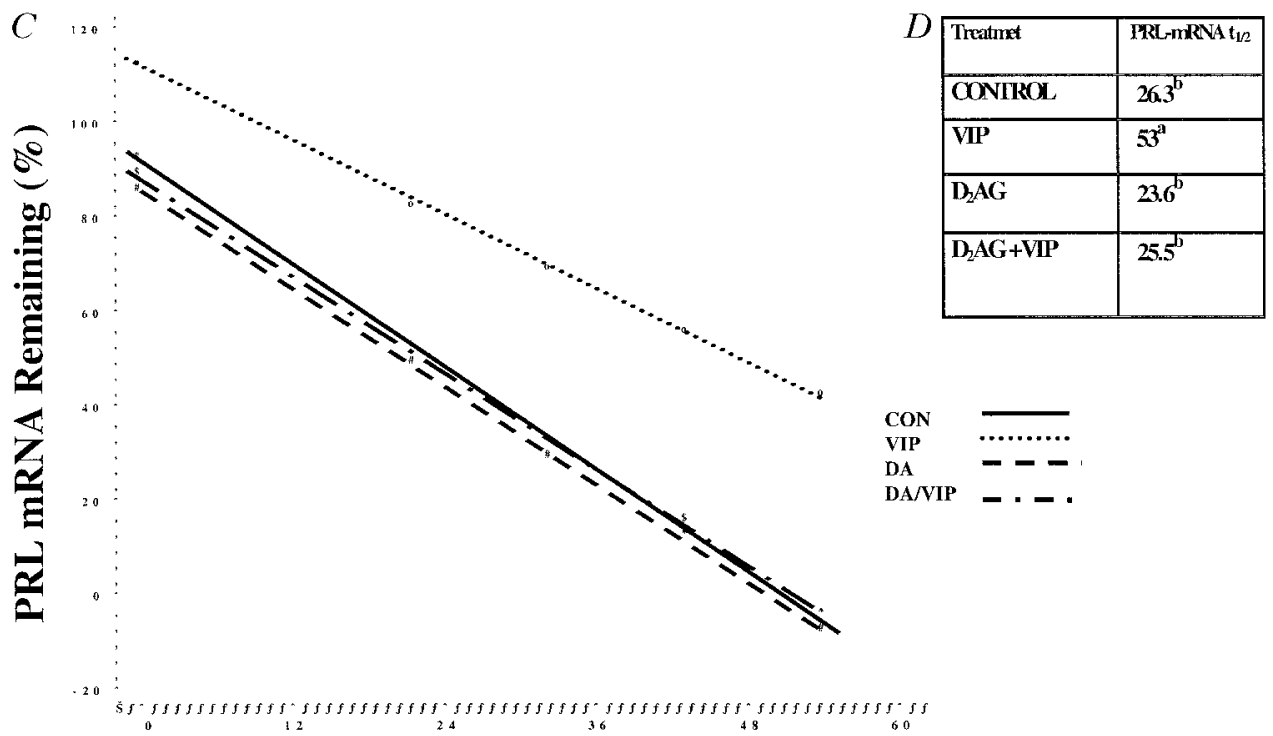

Hours Post Actinomycin D Treatment 
primary pituitary cells. This study will attempt to provide further understanding of the interplay between VIP and DA and of their roles in the modulation of PRL secretion and gene transcription in birds.

\section{Materials and methods}

\section{Experimental animals}

Adult large white female Nicholas turkeys (weighing $10-13 \mathrm{~kg}$ ) were used in these series of experiments. They were reared and housed on a $15 \mathrm{~h}$ light:9 $\mathrm{h}$ darkness lighting regimen in temperature-controlled $\left(15-21^{\circ} \mathrm{C}\right)$ floor pens, with food and water continuously available. All hens used were laying eggs (Youngren et al. 1996a). All hens were housed, handled and used in accordance with University of Minnesota Institutional Animal Care and Use Committee Guidelines.

\section{Pituitary tissue collection and cell dispersion}

Pituitary glands were collected from decapitated laying turkeys. The posterior lobes of the pituitary glands were removed, and the anterior lobes were dissociated using a modification of the trypsin/ neuraminidase procedure described by Hopkins \& Farquhar (1973). They were minced and replaced in Krebs-Ringer bicarbonate buffer solution (KRB, pH 7.4) supplemented with amino acids (MEM Eagle essential amino acids; BioWhittaker, Walkersville, MD, USA), $0.3 \mu \mathrm{g} / \mathrm{ml}$ glutamine sulfate (Sigma Chemical Co., St Louis, MO, USA), $2.5 \mathrm{mg} / \mathrm{ml}$ glucose (Sigma), $3 \mathrm{mg} / \mathrm{ml} \mathrm{BSA}$ (fraction $\mathrm{V}$, Sigma), and $100 \mu \mathrm{g} / \mathrm{ml}$ gentamycin sulfate (Sigma). Following mechanical shearing, pituitary fragments were digested enzymatically with $1 \mathrm{mg} / \mathrm{ml}$ trypsin (Sigma) and $2 \mu \mathrm{g} / \mathrm{ml}$ deoxyribonulease I (DNase I, Sigma) in KRB solution for $15 \mathrm{~min}$ at $37{ }^{\circ} \mathrm{C}$ in a shaking water bath. The supernatant was removed and replaced by a $\mathrm{Ca}^{2+} / \mathrm{Mg}^{2+}$-free supplemented KRB solution containing $2 \mathrm{mM}$ EDTA, disodium salt (Sigma). After 5 min of incubation at $37^{\circ} \mathrm{C}$, the supernatant was removed and replaced by a $\mathrm{Ca}^{2+} / \mathrm{Mg}^{2+}$-free supplemented KRB solution containing $1 \mathrm{mM}$ EDTA and $8 \mu \mathrm{g} / \mathrm{ml}$ neuraminidase (Sigma). After $15 \mathrm{~min}$ of incubation at $37^{\circ} \mathrm{C}$, the pituitary fragments were mechanically dispersed and the resultant cell suspension was filtered through $60 \mu \mathrm{m}$ mesh Nitex gauze (Genson Scientific, Middleboro, MA, USA) to remove undigested particles. Following centrifugation at 250-500 $\boldsymbol{g}$ for $15 \mathrm{~min}$, the supernatant was decanted and the cell pellet was resuspended in tissue culture medium consisting of medium M-199 (Life Technologies, Rockville, MD, USA) supplemented with $0.35 \mu \mathrm{g} /$ ml $\mathrm{NaHCO}_{3}, 3 \%$ charcoal-stripped turkey poult serum, $3 \%$ fetal calf serum (Sigma), $4 \cdot 8 \mu \mathrm{g} / \mathrm{ml}$ Hepes (Sigma), $1 \mu \mathrm{g} / \mathrm{ml}$ insulin (Sigma), $50 \mu \mathrm{g} / \mathrm{ml}$ gentamycin sulfate (Sigma), $100 \mathrm{U} / \mathrm{ml}$ penicillin (Sigma), $100 \mu \mathrm{g} / \mathrm{ml}$ streptomycin (Sigma) and $5 \mu \mathrm{g} / \mathrm{ml}$ amphotericin B (Sigma). Cell viability (90-95\%) was determined using the trypan blue dye exclusion and cell numbers were counted in a hemocytometer. The dispersed cells were initially incubated for $72 \mathrm{~h}$ in siliconized Erlenmeyer flasks at $38.5{ }^{\circ} \mathrm{C}$ in humidified atmosphere $\left(95 \% \mathrm{O}_{2}\right.$ and $5 \% \mathrm{CO}_{2}$ ) before conducting the experiments. After preincubation, cultured pituitary cells were pelleted and resuspended in a serum-free M-199 medium (Life Technologies) supplemented with $0 \cdot 1 \%$ BSA.

\section{Pituitary nuclei isolation}

Pituitary nuclei were isolated as previously described (Tong et al. 1998) with slight modifications. Briefly, pituitary cells were harvested by centrifugation and washed with diethylpyrocarbonate-treated

Figure 4 Effects of a $D_{2} A G$ and VIP on PRL mRNA stability. Cultured anterior pituitary cells were incubated for $48 \mathrm{~h}$ with vehicle, VIP $\left(10^{-7} \mathrm{M}\right), D_{2} A G R(-)$-propylnorapomorphine $\left(10^{-10} \mathrm{M}\right)$, or VIP $+D_{2} A G$. Actinomycin $D$ (inhibitor of mRNA synthesis) was then added to a final concentration of $5 \mu \mathrm{M}$. Cells $\left(0.5 \times 10^{6}\right.$ cells/treatment) were harvested at $0,24,36,48$ and $60 \mathrm{~h}$ and total RNA was extracted at the indicated times and analyzed by semi-quantitative RT-PCR. Regression analysis was performed to calculate PRL mRNA half-life. Results were converted to a percentage of the time zero values. There were two experiments with three replicates each $(n=6)$. (A) Representative photographs of separated RT-PCR products of PRL on ethidium bromide-stained agarose gel. (B) Relative quantification of PRL mRNA levels, which were normalized by $\beta$-actin mRNA levels. (C) Linear regression plots of the quantified PRL mRNA level, and (D) the calculated half-life of the PRL mRNA in each experimental condition. Significant differences are indicated by different superscripted letters. 
PBS. Nuclei were isolated by incubating the cells for $5 \mathrm{~min}$ on ice in a lysing buffer containing $50 \mathrm{mM}$ Tris- $\mathrm{HCl}, 140 \mathrm{mM} \mathrm{NaCl}, 1 \mathrm{mM} \mathrm{MgCl}_{2}$, $1 \mathrm{mM}$ dithiothreitol (DTT) and $0.5 \%$ Nonidet P-40, followed by centrifugation at $1000 \mathrm{~g}$. The nuclei were resuspended in a nuclear freezing buffer $\left(50 \mathrm{mM}\right.$ Tris- $\mathrm{HCl}$, pH $8 \cdot 3,5 \mathrm{mM} \mathrm{MgCl}_{2}$, $1 \mathrm{mM}$ DTT and $50 \%$ glycerol), snap frozen in liquid nitrogen, and stored at $-80{ }^{\circ} \mathrm{C}$ in aliquots of

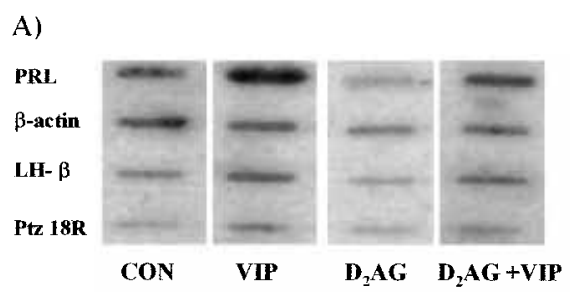

B

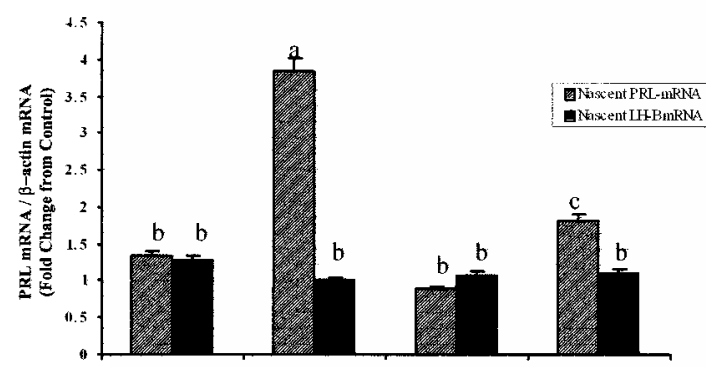

C)

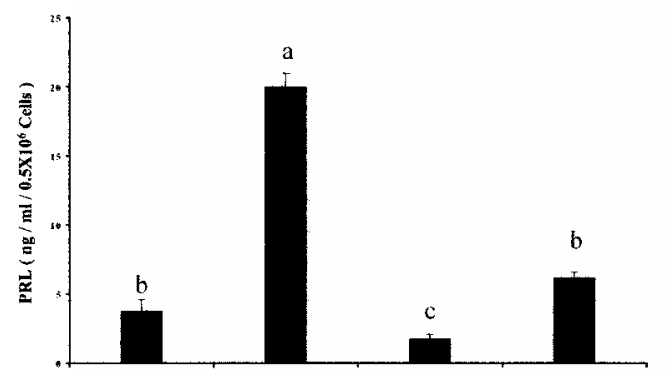

D1) CON VIP D,AG D,AG+VIP

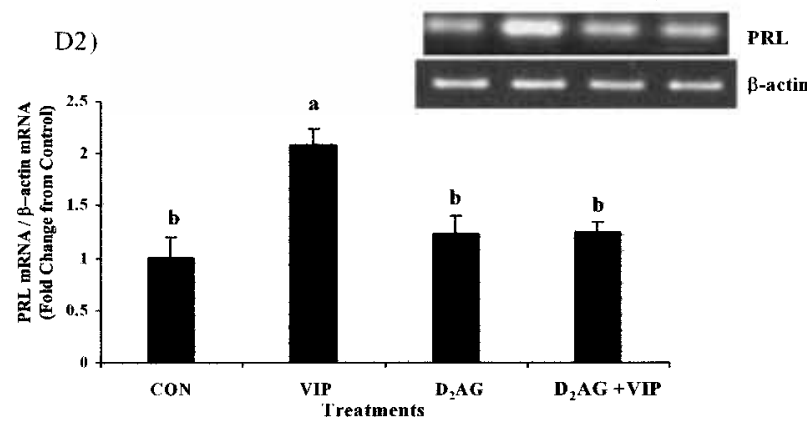

$10 \times 10^{6}$ nuclei/ $100 \mu \mathrm{l}$ until the NRO transcription assays were performed. The total cytoplasmic RNA in the supernatant was extracted by a commercial modification of the phenol-chloroform alcohol extraction method (RNeasy Mini Kit system; Qiagen Inc., Valencia, CA, USA) and stored at $-80{ }^{\circ} \mathrm{C}$ until used for semi-quantitative RT-PCR analysis.

\section{NRO transcription assay}

The NRO transcription assay was performed by combining several techniques from previously described methods (Preston et al. 1990, Delidow et al. 1991). In brief, nuclei were thawed on ice. The in vitro transcription reaction contained $10 \times 10^{6}$ nuclei in a mix of transcription buffer $(100 \mathrm{mM}$

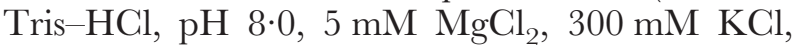
$0.5 \mathrm{mM}$ each of ATP, CTP and GTP, $150 \mu \mathrm{Ci}$ $\left[\alpha-{ }^{32} \mathrm{P}\right] \mathrm{UTP}$ (NEN Life Science, Boston, MA, USA), $10 \mathrm{mM}$ DTT, and $200 \mathrm{U}$ ribonuclease inhibitor (RNAsin; Promega, Madison, WI, USA)) for $45 \mathrm{~min}$ at $26^{\circ} \mathrm{C}$. The reaction was terminated by adding $20 \mathrm{U}$ of RNase-free DNase I (Promega) at $37^{\circ} \mathrm{C}$ for $15 \mathrm{~min}$. The nuclei were then deproteinized by the addition of protein kinase $\mathrm{K}(200 \mu \mathrm{g} / \mathrm{ml}$, Sigma $)$ for $30 \mathrm{~min}$ at $37^{\circ} \mathrm{C}$. Unincorporated nucleotides were removed using the Quick Spin Columns system (Boehringer Mannheim, Indianapolis, IN, USA). Newly synthesized RNA transcripts were isolated using the total RNA isolation protocol (RNeasy Mini Kit system; Qiagen). The labeled PRL, luteinizing hormone (LH) $-\beta$ and $\beta$-actin mRNA were quantified by hybridization to the PCR-synthesized turkey PRL,

Figure 5 Effects of the $D_{2} A G R(-)$-propylnorapomorphine on basal and VIP-stimulated PRL gene transcription rate in cultured turkey anterior pituitary cells. (A) NRO transcription assay was performed on nuclei from each treatment as described, equal counts of $\left.{ }^{32} \mathrm{P}\right]$ UTP-labeled nascent RNA were hybridized with PRL cDNA, $\beta$-actin cDNA, LH- $\beta$ cDNÃ and plasmid vector (Ptz 18R) DNA. (B) Results of NRO transcription assay were normalized to $\beta$-actin after subtracting non-specific binding and were expressed as means \pm S.E.M. $(n=5)$. (C) Effect of the $D_{2} A G$ on VIP-stimulated PRL release in the NRO experiment. (D 1 and 2) Representative photographs of separated RT-PCR products of cytoplasmic mRNA and relative quantification of PRL mRNA levels. Columns with different letters are significantly different $(P<0 \cdot 05)$. 
$\beta$-actin and LH- $\beta$ cDNA, and the full-length plasmid vector (Ptz 18R), which was previously immobilized ( $2 \mu \mathrm{g} /$ well) onto a Nytran membrane (ISCBioExpress, Kaysville, WT, USA) employing the described slot blot procedure (Ausubel et al. 1989). $\beta$-Actin cDNA and Ptz $18 \mathrm{R}$ vector DNA served as positive and negative controls respectively. Blots were prehybridized for $4 \mathrm{~h}$ at $42{ }^{\circ} \mathrm{C}$ in hybridization buffer $(50 \%$ formamide, $5 \times$ standard saline citrate $(\mathrm{SSC}), \quad 1 \% \quad \mathrm{SDS}, 7 \times$ Denhart's solution, $100 \mu \mathrm{g} / \mathrm{ml}$ salmon sperm DNA (Sigma) and $50 \mu \mathrm{g} / \mathrm{ml}$ yeast tRNA (Sigma)). Equal counts of radioactive elongated RNA $\left(0 \cdot 7-1 \times 10^{6}\right.$ c.p.m.) were then added to the blots and hybridized for $72 \mathrm{~h}$ at $42{ }^{\circ} \mathrm{C}$. After hybridization, the membranes were washed twice at room temperature for $15 \mathrm{~min}$ in $2 \times \mathrm{SSC}$ and $0.1 \% \mathrm{SDS}$, and three times at $65{ }^{\circ} \mathrm{C}$ for $20 \mathrm{~min}$ in $0 \cdot 1 \times \mathrm{SSC}$ and $0 \cdot 1 \% \mathrm{SDS}$. Membranes were then air-dried and exposed to Kodak X-ray film (Eastman Kodak, Rochester, $\mathrm{NY}$, USA) at $-80^{\circ} \mathrm{C}$ with the use of intensifying screen to minimize the time of exposure. Autoradiographic densities were quantified using NIH Image-J software (NIH, Bethesda, MD, USA).

\section{RNA extraction and semi-quantitative RT-PCR}

Total RNA was extracted from cultured pituitary cells using Trizol reagent (Gibco BRL, MD, USA) as recommended by the manufacturer with minor modifications. To reduce genomic DNA contamination, total RNA was treated with RNase-free DNase I (1 U/ $\mu \mathrm{g}$ RNA) for $30 \mathrm{~min}$ at $37^{\circ} \mathrm{C}$. After DNA digestion, total RNA was re-extracted using the total RNA isolation protocol (RNeasy Mini Kit system) and then RNA concentration was determined using a DU Series 500 spectrophotometer (Beckman, CA, USA). Total RNA (250 ng) was reverse-transcripted using SuperScript II reverse transcriptase and Oligo $\mathrm{dT}_{12-18}$ primers (Life Technologies) in a reaction volume of $20 \mu \mathrm{l}$ containing reverse transcriptase buffer $(50 \mathrm{mM}$ Tris-HCl, $75 \mathrm{mM} \mathrm{KCl,} 3 \mathrm{mM} \mathrm{MgCl}_{2}$, pH 8.4), $10 \mathrm{mM}$ DTT, $0.5 \mathrm{mM}$ of each dNTP, RNase inhibitor (RNAsin), $2.5 \mathrm{mM}$ Oligo $\mathrm{dT}_{12-18}$, and Superscript II TR (200 U), and then incubated at $42^{\circ} \mathrm{C}$ for $1 \mathrm{~h}$. The reaction was terminated by heating at $70{ }^{\circ} \mathrm{C}$ for $15 \mathrm{~min}$. Aliquots $(2 \mu \mathrm{l})$ of the resultant cDNA were used for the PCR reaction, which was performed in a $25 \mu \mathrm{l}$ volume containing $200 \mu \mathrm{M}$ of each dNTP, $50 \mathrm{mM} \mathrm{KCl}, 10 \mathrm{mM}$
Tris- $\mathrm{HCl}, \mathrm{pH} 8 \cdot 3,2 \mathrm{mM} \mathrm{MgCl}_{2}, 100 \mathrm{ng}$ genespecific sense and anti-sense primers, and $2.5 \mathrm{U}$ Ampli Taq DNA polymerase (Perkin Elmer, Norwalk, CT, USA). PGR profile consisted of an initial denaturation $\left(30 \mathrm{~min}, 94^{\circ} \mathrm{C}\right)$ followed by cycles of denaturation $\left(1 \mathrm{~min}, 94^{\circ} \mathrm{C}\right)$, annealing $\left(45 \mathrm{~s}, 60^{\circ} \mathrm{C}\right)$, extension $\left(1 \mathrm{~min}, 72^{\circ} \mathrm{C}\right)$, and a final extension for one cycle $\left(10 \mathrm{~min}, 72^{\circ} \mathrm{C}\right)$. The number of amplification cycles was 20-22 for PRL and 30 for $\beta$-actin, which were within the linear range of amplification. Primer sequences were as follows: PRL (sense, 5'-ACG TCG TTG CGA ATG TGG TGC AGT- 3'; anti-sense, 5'-GGA GTG CTG ATG AGG GAG TTG CAG- 3'; expected size of the PGR product, $523 \mathrm{bp}$ ), and $\beta$-actin (sense, 5'-ACG AGT AAT TGG TAG CGG CTG CTC- 3'; anti-sense, 5'-TGT GGT GGT ACG ACA ATG TAG CGT- 3'; expected size of the PGR product, $450 \mathrm{bp}$ ). RT-PGR products were separated in 2\% (2:1) agarose and NuSieve GTG gel (FMC Bioproducts, Rockland, ME, USA) and visualized with ethidium bromide. The gels were photographed and the intensities of the PCR products were quantified using NIH Image-J software. To correct for differences in RNA used in RT-PGR reactions, the band intensity for each RT-PCR product of PRL was normalized to that of $\beta$-actin from the same sample.

\section{PRL RIA}

Culture media were assayed for PRL content utilizing the homologous RIA described by Proudman \& Opel (1981). All samples from the same experiment were assayed simultaneously. All samples from each experiment were assayed in duplicate within a single assay.

\section{Drugs}

The drugs used were: $\mathrm{R}(-)$-propylnorapomorphine $\mathrm{HCl}$, a $\mathrm{D}_{2} \mathrm{AG},(+)-\mathrm{SKF}-38393$, a $\mathrm{D}_{1} \mathrm{AG}$, and $\mathrm{S}(-)$-eticlopride $\mathrm{HCl}, \mathrm{a}_{2} \mathrm{DA}$ receptor antagonist (Research Biochemicals International, Natick, MA, USA), chicken VIP (cVIP) (Peninsula Laboratory, San Carlos, CA, USA) and actinomycin D (Sigma).

\section{Statistical analysis}

The data from RIA, NRO assay and RT-PCR were analyzed using the general linear models 
procedure of the Statistical Analysis system (SAS 1987). Each datapoint represents the mean \pm S.E.M. of three independent experiments, with two replicates per experiment (data from NRO assays represent the means \pm s.E.M. of five independent experiments). Significant differences in mean values of PRL, nascent PRL mRNA or PRL mRNA levels between treatment groups were compared using Duncan's multiple range test. $P<0.05$ was considered statistically significant.

\section{Results}

\section{Experiment 1: effects of $D_{2} A G$ on basal and VIP-stimulated PRL mRNA levels and PRL release in turkey primary cultured pituitary cells}

The $\mathrm{D}_{2} \mathrm{AG}$ had no effect, at all concentrations used, on basal PRL mRNA steady-state levels in cultured pituitary cells after $3.5 \mathrm{~h}$ of incubation. On the other hand, the preincubation of pituitary cells with varying concentrations of the $\mathrm{D}_{2} \mathrm{AG}$ for 30 min resulted in a significant inhibition of VIPstimulated PRL mRNA levels at all concentrations used $\left(10^{-12}, 10^{-10}, 10^{-8}, 10^{-6}, 10^{-4} \mathrm{M}\right.$, $P<0 \cdot 05$, Fig. $1 \mathrm{~A}$ and $\mathrm{B})$. The maximum inhibitory effect of the $\mathrm{D}_{2} \mathrm{AG}$ was reached at a concentration of $10^{-10} \mathrm{M}$, but did not significantly differ from that observed with other concentrations. The incubation of pituitary cells with the $\mathrm{D}_{2} \mathrm{AG}$ resulted in inhibition of basal PRL release $(P<0 \cdot 05$, Fig. $1 \mathrm{C})$. Prior incubation of pituitary cells with the $\mathrm{D}_{2} \mathrm{AG}$ at concentrations of $0,10^{-12}, 10^{-10}$, $10^{-8}, 10^{-6}$ and $10^{-4} \mathrm{M}$ significantly inhibited VIP-stimulated PRL release in a dose-dependent manner $(30.4 \pm 1 \cdot 3,15 \cdot 6 \pm 0 \cdot 4,8.9 \pm 0 \cdot 1,6.9 \pm$ $0 \cdot 2,8 \cdot 2 \pm 0 \cdot 1$ and $10 \cdot 4 \pm 0 \cdot 3 \mathrm{ng} / \mathrm{ml}$ respectively). The maximum inhibitory effect of VIP-stimulated PRL release was observed at the $\mathrm{D}_{2} \mathrm{AG}$ concentration levels of $10^{-10}, 10^{-8}$ and $10^{-6} \mathrm{M}$.

\section{Experiment 2: effects of a $D_{1} A G$ on basal and VIP-stimulated PRL mRNA levels and PRL release in turkey primary cultured pituitary cells.}

To eliminate the possibility of the involvement of the $\mathrm{D}_{1} \mathrm{DA}$ receptor in the inhibitory effect of the $\mathrm{D}_{2} \mathrm{AG}$ on $\mathrm{PRL}$ gene expression observed in experiment 1, pituitary cells were incubated with different concentrations of the $\mathrm{D}_{1} \mathrm{AG}\left(10^{-12}\right.$, $\left.10^{-10}, 10^{-8}, 10^{-6}, 10^{-4} \mathrm{M}\right)$. Semi-quantitative RT-PCR analysis showed that the $\mathrm{D}_{1} \mathrm{AG}$ had no effect on basal or VIP-stimulated PRL mRNA in cultured pituitary cells $(P>0 \cdot 05$, Fig. $2 \mathrm{~A}$ and $\mathrm{B})$. Basal and VIP-stimulated PRL release were not affected by the different concentrations of $\mathrm{D}_{1} \mathrm{AG}$ added to the pituitary cells $(P>0.05$, Fig. 2C).

\section{Experiment 3: inhibitory effects of $D_{2} A G$ on VIP-stimulated PRL mRNA levels and PRL release in turkey primary cultured pituitary cells}

The $\mathrm{D}_{2} \mathrm{DA}$ receptor antagonist had no effect on basal or VIP-stimulated PRL mRNA levels and PRL release in pituitary cells. However, when the $\mathrm{D}_{2}$ DA receptor antagonist was added to the cultured pituitary cells $15 \mathrm{~min}$ prior to the $\mathrm{D}_{2} \mathrm{AG}$, it significantly antagonized the inhibitory effect of the $\mathrm{D}_{2} \mathrm{AG}$ on VIP-stimulated PRL mRNA levels $(P<0 \cdot 05$, Fig. 3A and B). Basal and VIP-stimulated PRL release were not inhibited by the $\mathrm{D}_{2} \mathrm{AG}$ when the pituitary cells were preincubated with the $\mathrm{D}_{2}$ DA receptor antagonist $(P>0 \cdot 05$, Fig. $3 \mathrm{C})$. The $\mathrm{D}_{2}$ DA receptor antagonist per se had no effect on basal or VIP-stimulated PRL release.

\section{Experiment 4: effects of $D_{2} A G$ and VIP on PRL mRNA stability in turkey primary cultured pituitary cells}

The effect of VIP and/or the $\mathrm{D}_{2} \mathrm{AG}$ on PRL mRNA stability in cultured pituitary cells was determined by measuring the half-life $\left(\mathrm{t}_{1 / 2}\right)$ of PRL mRNA, which was calculated by statistical regression of the data. VIP $\left(10^{-7} \mathrm{M}\right)$ significantly enhanced PRL mRNA stability $\left(\mathrm{t}_{1 / 2}=53.0 \mathrm{~h}\right)$ compared with that in non-treated control cells $\left(\mathrm{t}_{1 / 2}=26 \cdot 3 \mathrm{~h}\right)$ and in agonist-treated cells $\left(\mathrm{t}_{1 / 2}=\right.$ $23.6 \mathrm{~h})(P<0.05$, Fig. 4A and B). Preincubating pituitary cells with the $\mathrm{D}_{2} \mathrm{AG}$ resulted in a significant reduction in PRL mRNA half-life $\left(\mathrm{t}_{1 / 2}=\right.$ $25.5 \mathrm{~h})$ in VIP-treated pituitary cells $(P<0 \cdot 01)$. The $\mathrm{D}_{2} \mathrm{AG}$ had no effect on basal PRL mRNA $\mathrm{t}_{1 / 2}$ $(23 \cdot 6 \mathrm{~h})$. In non-actinomycin-treated control cells, PRL mRNA $t_{1 / 2}$ did not change throughout the experiment time course (data not shown). 


\section{Experiment 5: effects of $D_{2} A G$ on basal and VIP-stimulated PRL gene transcription rate in turkey primary cultured pituitary cells}

Nascent PRL mRNA increased by $3 \cdot 5 \pm 0 \cdot 3$-fold in VIP-stimulated pituitary cells in comparison with that of control cells $(P<0 \cdot 05$, Fig. 5A and $\mathrm{B})$. Preincubation of pituitary cells with the $\mathrm{D}_{2} \mathrm{AG}$ significantly reduced the stimulatory effect of VIP on nascent PRL mRNA $(P<0 \cdot 05)$. Nascent PRL mRNA was not altered $(P>0 \cdot 05)$ by the treatment of pituitary cells with the agonist alone. Nascent LH- $\beta$ and $\beta$-actin mRNA were not affected by the $\mathrm{D}_{2} \mathrm{AG}$ or VIP. Similar to the nascent PRL mRNA, cytoplasmic PRL mRNA steady-state level was $\sim 2 \cdot 5$-fold higher in VIP-stimulated pituitary cells than that of non-treated control cells $(P<0 \cdot 05$, Fig. $5 \mathrm{D} 1$ and D2). The $\mathrm{D}_{2} \mathrm{AG}$ significantly decreased the VIP stimulatory effect on PRL mRNA level $(P<0 \cdot 05)$. Basal and VIP-stimulated PRL release into the medium was reduced by the addition of the $\mathrm{D}_{2} \mathrm{AG}$ to the incubating medium $(P<0 \cdot 05$, Fig. $5 \mathrm{C})$.

\section{Discussion}

The present results show, for the first time in birds, that DA regulates PRL synthesis in cultured primary anterior pituitary cells. DA does this, in part, by antagonizing VIP-stimulated PRL gene transcription via $\mathrm{D}_{2} \mathrm{DA}$ receptors. The results also show that a $\mathrm{D}_{2} \mathrm{AG}$ reduces VIP-stimulated PRL mRNA steady-state level, PRL mRNA half-life, and PRL release at the pituitary level.

The avian PRF, VIP, is a potent stimulator of PRL release and PRL gene expression, both in vivo and in vitro (Macnamee et al. 1986, Opel \& Proudman 1988, El Halawani et al. 1990a,b, Xu et al. 1996). Conversely, as in the present study, $\mathrm{D}_{2} \mathrm{AGs}$ have been shown to inhibit VIP-stimulated PRL mRNA steady-state levels and PRL secretion by turkey pituitary cells (Xu et al. 1996). Our results show that VIP treatment increased PRL release into the medium by about 20- to 30-fold in comparison with that of untreated pituitary cells. In addition, the $\mathrm{D}_{2} \mathrm{AG}, \mathrm{R}(-)$-propylnorapomorphine, inhibited the basal and VIPstimulated PRL release in a dose-dependent manner. However, PRL mRNA steady-state level responded differently to the action of the $\mathrm{D}_{2} \mathrm{AG}$. The agonist had no effect on basal PRL mRNA levels and its effect on VIP-stimulated PRL mRNA appeared to be all or none. Two possibilities may explain the differences in the PRL secretion mechanism(s) in its response to DA: (i) PRL gene expression may be more sensitive to the inhibitory effect of DA than PRL release - lower concentrations of the agonist than the ones used in the present study might show a dose-response effect, if it exists; alternatively (ii) circulating PRL levels may be fine-tuned by the relative activity of the inhibitory and stimulatory influences of DA on PRL release (Youngren et al. 1995, 1996b), since PRL release is under tonic stimulation by VIP (El Halawani et al. 1997). This latter possibility may also explain the findings that activation of $\mathrm{D}_{2} \mathrm{DA}$ receptors inhibited basal PRL release, whereas it had no effect on basal PRL mRNA levels.

Changes in PRL mRNA levels can occur because of changes in transcription and/or post-transcription events. The present results show that the $\mathrm{D}_{2} \mathrm{AG}, \mathrm{R}(-)$-propylnorapomorphine, significantly inhibited the stimulatory effect of VIP on PRL mRNA at the transcriptional level. Previous studies in mammals have demonstrated the involvement of the pituitary-specific transcription factor (Pit-1, GHF-1) in the hormonal regulation of PRL transcriptional activity, including the inhibitory response to DA (Iverson et al. 1990, Elsholtz et al. 1991, Yan \& Bancroft 1991). Recent work shows that the inhibition of PRL gene transcription by DA is conferred by proximal promoter sequences and that binding sites for Pit-1 are important in this response (Elsholtz et al. 1991, Lew et al. 1994). A conserved consensus Pit-1binding site has been proposed in the avian and teleost PRL/growth hormone gene family (Ohkubo et al. 1996). Pit-1 cDNA has been cloned in the turkey (Wong et al. 1992, Kurima et al. 1998) and chicken (Tanaka et al. 1999).

These findings, taken together with the results of the present study, suggest that the inhibitory effect of DA on VIP-induced PRL gene transcription may result from DA suppression of the transactivating function of Pit-1, which is mediated by a pertussis toxin-sensitive $G$ protein, especially $G_{o \alpha}$ or $\mathrm{G}_{\mathrm{i} \alpha 2}$. The major transactivating domain of mammalian Pit-1 has been localized to the N-terminal region and found to be suppressed by DA (Lew \& Elsholtz 1995). Studying the structure and transcription-initiating mechanism of the chicken PRL gene indicates the involvement of Pit-1 and cAMP in the activation of PRL gene 
expression (Ohkubo et al. 2000). However, such a suggestion must be taken with caution as the results of a recent study revealed the absence of Pit-1 protein in turkey lactotrophs (Weatherly et al. 2001).

The inhibition of transcription rate by DA was not the only determinant of the inhibitory effect of DA on the steady-state levels of PRL mRNA; the decay rate (half-life) was also inhibited by DA. Consistent with a previous study on turkey pituitary cells (Tong et al. 1998), VIP significantly increased PRL mRNA half-life from $26.3 \mathrm{~h}$ in control cultures to $53.0 \mathrm{~h}$ in VIP-treated cells, an effect that was reversed by pre-incubating the cells with the $\mathrm{D}_{2} \mathrm{AG}$. This is the first time that the inhibitory effect of DA on PRL mRNA stability has been demonstrated in avian or mammalian species. The molecular mechanism(s) by which activation of $\mathrm{D}_{2}$ DA receptors destabilizes PRL mRNA half-life remains to be clarified. Alterations in one or more of the following mechanisms may be involved: (i) the length of the PRL mRNA poly (A) tail (Diamond \& Goodman, 1985, Jones et al. 1990), (ii) the effect on the destabilizing sequence elements, such as AU-rich elements, if they exist (Shaw \& Kamen 1986), or (iii) the RNA-binding proteins which play a major role in regulating the mRNA half-life (Staton et al. 2000).

Unlike the inhibitory effect of pituitary $\mathrm{D}_{2} \mathrm{DA}$ receptors, $\mathrm{D}_{1}$ DA receptor activation showed neither a stimulatory nor inhibitory influence on PRL mRNA expression or release. These results are in agreement with earlier findings from our laboratory (Youngren et al. 1998). $\mathrm{D}_{1}$ DA receptors are not found on mammalian pituitary cells (Rovescalli et al. 1987, Sunahara et al. 1991). In contrast, three $\mathrm{D}_{1}$ DA receptor subtypes have been identified and quantified in the turkey pituitary across the reproductive cycle (Schnell et al. 1999, Chaiseha et al. 2003).

In conclusion, the present results show, for the first time in an avian species, that DA inhibits VIP-stimulated PRL mRNA at the transcriptional and post-transcriptional (PRL mRNA half-life) levels via pituitary $\mathrm{D}_{2} \mathrm{DA}$ receptors.

\section{Acknowledgement}

This research was supported by USDA grant No. 00-35203-9157.

\section{References}

Al-Zailaie K \& El Halawani ME 2000 Neuroanatomical relationship between immunoreactive dopamine and vasoactive intestinal peptide neurons in the turkey hypothalamus. Poultry Science 7950.

Ausubel FM, Brent R, Kingston RE, Moore DD, Smith JA, Seioman JG \& Struhl K 1989 Current Protocol in Molecular Biology. Brooklyn, NY: Greene Publishing Associates.

Ben-Jonathan N \& Hnasko R 2001 Dopamine as a prolactin (PRL) inhibitor. Endocrine Reviews 22 724-763.

Ben-Jonathan N, Oliver C, Weiner HJ, Mical RS \& Porter JC 1977 Dopamine in hypophysial portal plasma of the rat during the estrous cycle and throughout pregnancy. Endocrinology $\mathbf{1 0 0} 452-458$.

Ben-Jonathan N, Arbogast LA \& Hyde JF 1989 Neuroendocrine regulation of prolactin release. Progress in Neurobiology 33 399-447.

Bern HA \& Nicoll CS 1968 The comparative endocrinology of prolactin. Recent Progress in Hormone Research 24 681-720.

Camper SA, Yao YA \& Rottman FM 1985 Hormonal regulation of the bovine prolactin promoter in rat pituitary tumor cells. Fournal of Biological Chemistry 260 12246-12251.

Chaiseha Y, Youngren OM, Al-Zailaie K \& El Halawani ME 2003 Expression of $D_{1}$ and $D_{2}$ dopamine receptors in the hypothalamus and pituitary during the turkey reproductive cycle: colocalization with vasoactive intestinal peptide. Neuroendocrinology 77 105-118.

Curlewis JD, Kusters DH, Barclay JL \& Anderson ST 2002 Prolactin-releasing peptide in the ewe: cDNA cloning, mRNA distribution and effects on prolactin secretion in vitro and in vivo. Fournal of Endocrinology 174 45-53.

Delidow BC, Billis WM, Agarwal P \& White BA 1991 Inhibition of prolactin gene transcription by transforming growth factor-beta in $\mathrm{GH}_{3}$ cells. Molecular Endocrinology 5 1716-1722.

Diamond DJ \& Goodman HM 1985 Regulation of growth hormone messenger RNA synthesis by dexamethasone and triiodothyronine: transcriptional rate and mRNA stability changes in pituitary tumor cells. Fournal of Molecular Biology 181 41-62.

El Halawani ME, Silsby JL \& Mauro LJ 1990a Enhanced vasoactive intestinal peptide-induced prolactin secretion from anterior pituitary cells of incubating turkeys (Meleagris gallopavo). General and Comparative Endocrinology 80 138-145.

El Halawani ME, Silsby JL \& Mauro LJ $1990 b$ Vasoactive intestinal peptide is a hypothalamic prolactin releasing neuropeptide in the turkey (Meleagris gallopavo). General and Comparative Endocrinology 78 $66-73$.

El Halawani ME, Youngren OM \& Pitts GR 1997 Vasoactive intestinal peptide as the avian prolactin-releasing factor. In Perspectives in Avian Endocrinology, pp 403-416. Eds S Harvey \& R Etches. Bristol: Society For Endocrinology.

El Halawani ME, Youngren OM \& Chaiseha Y 2000 Neuroendocrinology of prolactin regulation in the domestic turkey. In Avian Endocrinology, pp 233-244. Eds A Dawson \& CM Chaturvedi. New Delhi: Narosa Publishing House.

Elsholtz HP, Lew AM, Albert PR \& Sundmark VC 1991 Inhibitory control of prolactin and Pit-1 gene promoters by dopamine: dual signaling pathways required for $\mathrm{D}_{2}$ receptor-regulated expression of the prolactin gene. Fournal of Biological Chemistry $\mathbf{2 6 6}$ 22919-22925.

Fischberg DJ \& Bancroft C 1995 The $\mathrm{D}_{2}$ receptor blocked transcription in GH3 cells and cellular pathways employed by D2A to regulate prolactin promoter activity. Molecular and Cellular Endocrinology 111 129-137.

Freeman ME, Kanyicska B, Lerant A \& Nagy G 2000 Prolactin: structure, function, and regulation of secretion. Physiological Reviewes 80 1523-1631.

Hall TR \& Chadwick A 1983 Hypothalamic control of prolactin and growth hormone secretion in the pituitary gland of the pigeon and the chicken: in vitro studies. General and Comparative Endocrinology 49 $135-143$. 
Hall TR \& Chadwick A 1984 Dopaminergic inhibition of prolactin release from pituitary glands of the domestic fowl incubated in vitro. Fournal of Endocrinology 103 63-69.

Hinuma S, Habata Y, Fujii R, Kawamata Y, Hosoya M, Fukusumi S, Kitada C, Masuo Y, Asano T, Matsumoto H et al. 1998 A prolactin-releasing peptide in the brain. Nature 393 272-276.

Hopkins CR \& Farquhar MG 1973 Hormone secretion by cells dissociated from rat anterior pituitaries. Fournal of Cell Biology $\mathbf{5 9}$ 277-303.

Iverson RA, Day KH, d'Emden M, Day RN \& Maurer RA 1990 Clustered point mutation analysis of the rat prolactin promoter. Molecular Endocrinology 4 1564-1571.

Jones PM, Burrin JM, Ghatei MA, O'Halloran DJ, Legon S \& Bloom SR 1990 The influence of thyroid hormone status on the hypothalamo-hypophyseal growth hormone axis. Endocrinology 126 1374-1379.

Kanasaki H, Yonehara T, Yamamoto H, Takeuchi Y, Fukunaga K, Takahashi K, Miyazaki K \& Miyamoto E 2002 Differential regulation of pituitary hormone secretion and gene expression by thyrotropin-releasing hormone. A role for mitogen-activated protein kinase signaling cascade in rat pituitary GH3 cells. Biology of Reproduction 67 107-113.

Kiss JZ \& Peczely P 1987 Distribution of tyrosine-hydroxylase (TH)-immunoreactive neurons in the diencephalon of the pigeon (Columba livia domestica). Fournal of Comparative Neurology 257 333-346.

Kragt CL \& Meites J 1965 Stimulation of pigeon pituitary prolactin release by pigeon hypothalamic extract in vitro. Endocrinology $\mathbf{7 6}$ 1169-1176.

Kurima K, Weatherly KL, Sharova L \& Wong EA 1998 Synthesis of turkey Pit-1 mRNA variants by alternative splicing and transcription initiation. DNA and Cell Biology 17 93-103.

Lew AM \& Elsholtz HP 1995 A dopamine-responsive domain in the $\mathrm{N}$-terminal sequence of Pit 1: transcriptional inhibition in endocrine cell types. Fournal of Biological Chemistry 270 7156-7160.

Lew AM, Yao H \& Elsholtz HP 1994 G(i) alpha 2- and G(o) alpha-mediated signaling in the Pit-1-dependent inhibition of the prolactin gene promoter: control of transcription by dopamine D2 receptors. Fournal of Biological Chemistry 269 12007-12013.

Macnamee MC \& Sharp PJ 1989 The functional activity of hypothalamic dopamine in broody bantam hens. Fournal of Endocrinology $12167-74$.

Macnamee MC, Sharp PJ, Lea RW, Sterling RJ \& Harvey S 1986 Evidence that vasoactive intestinal polypeptide is a physiological prolactin-releasing factor in the bantam hen. General and Comparative Endocrinology 62 470-478.

Moons L, van Gils J, Ghijsels E \& Vandesande F 1994 Immunocytochemical localization of L-dopa and dopamine in the brain of the chicken (Gallus domesticus). Fournal of Comparative Neurology 346 97-118.

Ohkubo T, Araki M, Tanaka M, Sudo S \& Nakashima K 1996 Molecular cloning and characterization of the yellowtail GH gene and its promoter: a consensus sequence for teleost and avian Pit-1/GHF-1 binding sites. Fournal of Molecular Endocrinology 16 $63-72$.

Ohkubo T, Tanaka M \& Nakashima K 2000 Molecular cloning of the chicken prolactin gene and activation by Pit- 1 and cAMP-induced factor in $\mathrm{GH}_{3}$ cells. General and Comparative Endocrinology 119 208-216.

Opel H \& Proudman JA 1988 Stimulation of prolactin release in turkeys by vasoactive intestinal peptide. Proceedings of the Society for Experimental Biology and Medicine 187 455-460.

Pasqualini C, Bojda F, Gaudoux F, Guibert B, Leviel V, Teissier E, Rips R \& Kerdelhue B 1988 Changes in tuberoinfundibular dopaminergic neuron activity during the rat estrous cycle in relation to the prolactin surge: alteration by a mammary carcinogen. Neuroendocrinology 48 320-327.
Preston GM, Billis WM \& White BA 1990 Transcriptional and posttranscriptional regulation of the rat prolactin gene by calcium. Molecular Cell Biology 10 442-448.

Proudman JA \& Opel H 1981 Turkey prolactin: validation of radioimmunoassay and measurement of changes associated with broodiness. Biology of Reproduction 25 573-580.

Reiner A, Karle EJ, Anderson KD \& Medina L 1994 Catecholaminergic perikarya and fibers in the avian nervous system. In Phylogeny and Development of Catecholamine Systems in CNS of Vertebrates, pp 135-181. Eds WJAJ Smeets \& A Reiner. Cambridge: Cambridge University Press.

Rovescalli AC, Brunello N, Monopoli A, Ongini E \& Racagni G 1987 Absence of $\left[{ }^{3} \mathrm{H}\right] \mathrm{SCH} 23390$ specific binding sites in anterior pituitary: dissociation from effects on prolactin secretion. European Fournal of Pharmacology 135 129-136.

SAS 1987 User's Guide: Version 7. Cary, NC: SAS Institute.

Schnell SA, You S \& El Halawani ME $1999 \mathrm{D}_{1}$ and $\mathrm{D}_{2}$ dopamine receptor messenger ribonucleic acid in brain and pituitary during the reproductive cycle of the turkey hen. Biology of Reproduction $\mathbf{6 0}$ 1378-1383.

Shaw G \& Kamen RA 1986 Conserved AU sequence from the 3' untranslated region of GM-CSF mRNA mediates selective mRNA degradation. Cell $\mathbf{4 6}$ 659-667.

Staton JM, Thomson AM \& Leedman PJ 2000 Hormonal regulation of mRNA stability and RNA-protein interactions in the pituitary. Fournal of Molecular Endocrinology 25 17-34.

Sunahara RK, Guan HC, O'Dowd BF, Seeman P, Laurier LG, Ng G, George SR, Torchia J, Van Tol HHM \& Niznik HB 1991 Cloning of the gene for a human dopamine $\mathrm{D}_{5}$ receptor with higher affinity for dopamine than $\mathrm{D}_{1}$. Nature $\mathbf{3 5 0}$ 614-619.

Tanaka M, Yamamoto I, Ohkubo T, Wakita M, Hoshino S \& Nakashima K 1999 cDNA cloning and developmental alterations in gene expression of the two Pit-1/GHF-1 transcription factors in the chicken pituitary. General and Comparative Endocrinology 114 441-448.

Taylor MM \& Samson WK 2001 The prolactin releasing peptides: RF-amide peptides. Cellular and Molecular Life Sciences $\mathbf{5 8}$ 1206-1215.

Tong Z, Pitts GR, You S, Foster DN \& El Halawani ME 1998 Vasoactive intestinal peptide stimulates turkey prolactin gene expression by increasing transcription rate and enhancing mRNA stability. Fournal of Molecular Endocrinology 21 259-266.

Weatherly KL, Ramesh R, Strange H, Waite KL, Storrie B, Proudman JA \& Wong EA 2001 The turkey transcription factor Pit-1/GHF-1 can activate the turkey prolactin and growth hormone gene promoters in vitro but is not detectable in lactotrophs in vivo. General and Comparative Endocrinology 123 244-253.

Wong EA, Silsby JL \& El Halawani ME 1992 Complementary DNA cloning and expression of Pit-1/GHF-1 from the domestic turkey. DNA and Cell Biology 11 651-660.

Xu M, Proudman JA, Pitts GR, Wong EA, Foster DN \& El Halawani ME 1996 Vasoactive intestinal peptide stimulates prolactin mRNA expression in turkey pituitary cells: effects of dopaminergic drugs. Proceedings of the Society for Experimental Biology and Medicine 212 52-62.

Yan GZ \& Bancroft C 1991 Mediation by calcium of thyrotropinreleasing hormone action on the prolactin promoter via transcription factor pit-1. Molecular Endocrinology 5 1488-1497.

Yan GZ, Pan WT \& Bancroft C 1991 Thyrotropin-releasing hormone action on the prolactin promoter is mediated by the POU protein Pit-1. Molecular Endocrinology 5 535-541.

Youngren OM, Pitts GR, Phillips RE \& El Halawani ME 1995 The stimulatory and inhibitory effects of dopamine on prolactin secretion in the turkey. General and Comparative Endocrinology $\mathbf{9 8}$ $111-117$. 
Youngren OM, Chaiseha Y, Phillips RE \& El Halawani ME $1996 a$ Vasoactive intestinal peptide concentrations in turkey hypophyseal portal blood differ across the reproductive cycle. General and Comparative Endocrinology 103 323-330.

Youngren OM, Pitts GR, Phillips RE \& El Halawani ME $1996 b$ Dopaminergic control of prolactin secretion in the turkey. General and Comparative Endocrinology 104 225-230.

Youngren OM, Chaiseha Y \& El Halawani ME 1998 Regulation of prolactin secretion by dopamine and vasoactive intestinal peptide at the level of the pituitary in the turkey. Neuroendocrinology $\mathbf{6 8}$ 319-325.

Yuan ZF \& Pan JT 2002 Involvement of angiotensin II, TRH and prolactin-releasing peptide in the estrogen-induced afternoon prolactin surge in female rats: studies using antisense technology. Life Sciences 71 899-910.

Received in final form 5 March 2003

Accepted 24 March 2003 